\title{
Development of Online-based Inquiry Learning Model to Improve 21st-Century Skills of Physics Students in Senior High School
}

\author{
Fuja Novitra ${ }^{1 *}$, Festiyed $^{2}$, Yohandri $^{2}$, Asrizal $^{2}$ \\ 1 Doctoral Program of Education Science, Universitas Negeri Padang, Padang, INDONESIA \\ 2 Faculty of Mathematics and Natural Sciences, Universitas Negeri Padang, INDONESIA
}

Received 2 June 2021 - Accepted 11 August 2021

\begin{abstract}
In the technological disruption era, education goals have evolved to emphasize students to possess $21^{\text {st }}$-Century Skills. Learning model capable of accommodating these skills is a model that has a balance between a scientific approach and the use of technology. This research aims to develop a valid, practical, and effective Online-based Inquiry learning model to improve the $21^{\text {st }}$ Century Skills of physics students in senior high school. This research was research and development $(R \& D)$. The stages of model development consisted of preliminary research, prototyping phases, and assessment phases. The model was validated by five experts. Sixty tenthgrade students participated in the field test. The results showed that the validity of the model is on very high category. The practicality of the model is on very practical category. The average level of the students' $21^{\text {st }}$-Century Skills is 84.72 , while the average $\mathrm{N}$-Gain scores is 0.63 . Based on these results, the model fulfills the valid, practical, and effective category for improving students' $21^{\text {st }}$-Century Skills and is expected to be an alternative reference to enhance the quality of physics learning and other fields of science.
\end{abstract}

Keywords: 21st-century skills, inquiry, learning model, online learning

\section{INTRODUCTION}

Physics is a science that is synonymous with observation and experiment. According to Urone et al. (2020), and Zais (1976), Leonardo da Vinci, Galileo, and Newton created physics science by performing observations and elaborations of reasoning on the universe as a project of investigation. Performing observations and elaborations of reasoning like a scientist have broad support in the research literature as the best way for students to gain a mature understanding of physics (Furtak \& Penuel, 2019). This is also stated in the NGSS (standards of USA pedagogical practices in K-12 science instruction) that physics learning has to require students to engage and reflect on phenomena and the universe (Calmer, 2019). One of the methods that can enable students to perform these scientific practices is inquiry-based learning (Aditomo \& Klieme, 2020; Bevins \& Price, 2016; Burgin, 2020; Choy et al., 2016; NRC, 2013; Pedaste et al., 2015). The Republic of Indonesia Ministry of Education and Culture Regulation Number 22 of 2016 also suggests applying inquiry in physics learning. However, in the current technological disruption era, there are "new" skills that are highly in demand and need to be owned by students, while considering "old" educational praxis irrelevant (Ahonen \& Kinnunen, 2015; Bernhardt, 2015; Boyaci \& Atalay, 2016; Donovan et al., 2014; van Laar et al., 2017).

These skills are 21 1 st_Century Skills, which are recognized as competency standards that need to be possessed by students to fulfill the demands of success in their work and future life (Asrizal et al., 2018; Ball et al., 2016; Binkley et al., 2012; Partnership for 21st Century, 2019). Learning in schools needs to be able to provide experiences and opportunities that stimulate students to possess these skills (Ahonen \& Kinnunen, 2015; Bernhardt, 2015; Boyaci \& Atalay, 2016; Donovan et al., 2014). In other words, physics subjects are responsible for organizing learning capable of improving students' $21^{\text {st_Century Skills. }}$

Several studies have been carried out to organize learning capable of improving the 21st-Century Skills of students, especially in Indonesia. On the Sinta Indonesia

(c) 2021 by the authors; licensee Modestum. This article is an open access article distributed under the terms and conditions of the Creative Commons Attribution License (http://creativecommons.org/licenses/by/4.0/).

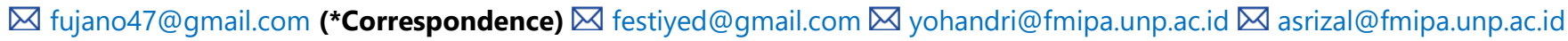




\section{Contribution to the literature}

- 21st-Century Skills are skills that include ICT literacy, hence their holistic development can be realized through the development of $4 \mathrm{C}$ skills (creativity, critical thinking, collaboration, and communication) in a digital context.

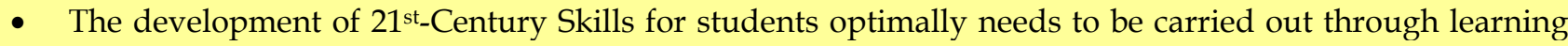
that has a balance between a scientific approach and the use of technology.

- The results showed that Online-based Inquiry is a valid, practical, and effective learning model in developing 21 $1^{\text {st }}$ Century Skills of students in senior high school physics learning.

website, hundreds of studies funded by the Ministry of Research, Technology, and Higher Education related to

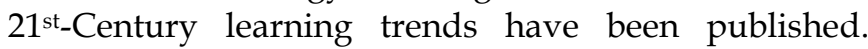
However, irrespective of these numbers of publications, optimal results have not been obtained, especially in physics learning. This is because the solutions offered are not yet in a complete form of learning design, like a learning model. According to Gilbert \& Justi (2016) and Reigeluth et al. (2016), the use of learning models optimizes the process of developing student competencies in accordance with the goals set. This is because it covers all aspects of learning that have internal consistency between its components, such as methods, teaching materials, media, and assessments in sync with each other (Arends, 2009; Joyce et al., 2016). Reputable articles related to physics learning in Indonesia published from 2012-2019 were dominated by the development of media, teaching materials, or other learning components (Nurhasanah et al., 2020). As a result, systematic activities in the classroom have not been carried out optimally.

Existing learning models developed in preliminary studies show relatively positive results, such as the development of blended learning (Dwianto et al., 2017), e-learning (Muliyati et al., 2019), Project-Based Learning based on STEM (Syukri et al., 2021), as well as discoveryinquiry (Tompo et al., 2016). However, these models are not enough to accommodate the $21^{\text {st_Century Skills }}$ development needs of students in physics learning. Although these models effectively improve learning outcomes, they are unable to accommodate students in

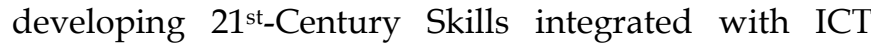
literacy. The PjBL model based on STEM and discoveryinquiry emphasizes on scientific approach without integrating ICT at the infusing or transforming level. Furthermore, the model based on blended learning and e-learning emphasizes integrating ICT in the transforming level without emphasizing the scientific approach. Therefore, these models do not optimally

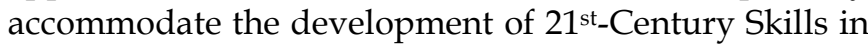
physics learning. Based on the 21 ${ }^{\text {st_Century Skills }}$ framework as defined by AASL (2019), NRC (2013), and Partnership for 21st Century (2019), these skills include ICT literacy. Indicators for creativity, critical thinking, collaboration, and communication must be observed in a digital context (van Laar et al., 2020). The characteristic of this model is a learning model that configures ICT in each phase. Students are given opportunities to demonstrate creativity and critical thinking through the use of ICT tools. Classroom management strategies should promote communication and collaboration in two forms (in-person and online). Technology is used to reflect learning in the classroom (Donovan et al., 2014). In other words, learning capable of accommodating the development of $21^{\text {st }}$ Century Skills in physics learning has a balance between a scientific approach and the use of technology. Irrespective of the ability of digital technology to provide a variety of tools that make it easier for students to learn, direct interaction between teachers, students, and technology are inseparable in developing their overall abilities in the $21^{\text {st }}$ Century (Ayvaz Tunç, 2017; Wang, 2008; Webb \& Gibson, 2015).

This phenomenon shows that the learning model that only uses constructivist theory as the basis for its development is no longer relevant today. Similarly, according to Adnan \& Anwar (2020), online learning is no better than conventional learning in developing countries because it requires large internet bandwidth to accommodate interactions between teachers and students and students with their peers. Furthermore, many factors, such as the availability of virtual laboratories, internet speed, and students' digital literacy levels, cannot be fulfilled optimally (Dhawan, 2020).

Therefore, based on these gaps, it is important to determine a learning model with a balance between a scientific approach and the use of technology as a learning model that combines elements of constructivism and connectivism. This solution is actualized through an ICT-integrated inquiry learning model at the infusing level.

\section{RESEARCH PURPOSE}

The purpose of this research is to develop a valid, practical, and effective Online-based Inquiry learning model capable of improving students' $21^{\text {st_Century }}$ Skills. This learning model is expected to improve the quality of physics learning and provide a learning experience in accordance with the current era. Furthermore, this research is expected to act as an alternative reference to improve the quality of learning in other fields of science. 


\section{METHODOLOGY}

\section{Research Design}

This research and development study aims to develop a valid, practical, and effective Online-based Inquiry learning model using the Plomp model. According to Plomp and Nieveen (2013), the steps of this development model are preliminary research, prototyping, and assessment phases. In preliminary research, a need and context analysis, literature review, and the development of a conceptual framework for the Online-based Inquiry learning model were conducted. Needs and context analysis consists of inquiry-based learning, student, curriculum, and material analyses. The preliminary research results were a state-of-the-art and conceptual framework design of Online-based Inquiry learning model. The product design of the Online-based Inquiry learning model is carried out in the prototyping phase, which consists of a model book, teacher e-book, student e-book, and 21 ${ }^{\text {st_Century Skills }}$ assessment instrument. The instruments used to assess development products are validated first using the validation instrument assessment sheet. After the instrument is declared valid by the experts, selfevaluation of the product is conducted. Subsequently, five experts in education science, physics learning media, physics education, educational technology, and the Indonesian language validated the product development. Validation referred to indicators of content, construct, and language validity assessment. After being declared valid, the product is evaluated through one-to-one, small group evaluation, and field test. Furthermore, a summative evaluation is carried out in the assessment phase to conclude whether the Onlinebased learning model is practical and effective in

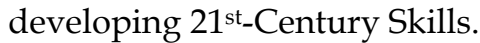

\section{Research Subjects}

Field tests are carried out at senior high schools in two regencies/cities in Jambi Province, namely State Senior High Schools (SSHS) 1 Sungai Penuh, 3 Sungai Penuh, and 7 Kerinci. The three senior high schools are selected using a cluster random sampling technique based on the 2019 National Examination scores, and in the high, middle, and low categories. The subjects were tenth-grade students majoring in Mathematics and Natural Sciences and consisted of 20 students in each school.

\section{Instruments and Data Analysis}

The research instruments used to collect data were validity assessment, practicality assessment, and $21^{\text {st }}$ Century Skills assessment. The validity analysis uses a Likert scale. The calculation of the final value data from the validation results is carried out using the Aiken's V equation (Azwar, 2014), as follows:

$$
V=\frac{\sum \text { Scores from expert }- \text { The lowest score in the category }}{[\text { Number of categories }(\text { Number of experts }-1)]}
$$

The validity level of the developed product is based on five categories, namely invalid $(\mathrm{V} \leq 0.00)$, low validity $(0.001 \leq \mathrm{V} \leq 0.400)$, moderate validity $(0.401 \leq \mathrm{V} \leq 0.600)$, high validity $(0.601 \leq \mathrm{V} \leq 0.800)$, and very high validity $(0.801 \leq \mathrm{V} \leq 1.000)$ (Arikunto, 2015).

Practicality data analysis was obtained from the questionnaire instrument for teacher and student responses to the learning model. The indicators included the ease of following the learning model, the usefulness in physics learning, the usability of e-books, and time allocation. The practicality analysis uses a Likert scale, which is calculated to determine the final value data from the practicality results using Equation 2.

$$
P=\frac{\text { Scores from rater }}{\text { Maximum Score }} \times 100
$$

The practicality assessment is based on five categories, namely not practical $(0 \leq \mathrm{P} \leq 20)$, less practical $(21 \leq \mathrm{P} \leq 40)$, quite practical $(41 \leq \mathrm{P} \leq 60)$, practical $(61 \leq \mathrm{P} \leq 80)$, and very practical $(81 \leq \mathrm{P} \leq 100)$ (Riduwan, 2009).

The effectiveness analysis of the Online-based Inquiry learning model is obtained from the $21^{\text {st_Century }}$ Skills assessment instrument, which includes performance and peer assessments. The 21 st_Century Skills analysis in each sub-evaluation uses Equation 3.

$$
N=\frac{\text { Number of the student scores }}{\text { Maximum Score }} \times 100
$$

The assessment is categorized based on five categories, namely very low $(0 \leq \mathrm{N} \leq 29)$, low $(30 \leq \mathrm{N} \leq 64)$, adequate $(65 \leq \mathrm{N} \leq 79)$, high $(80 \leq \mathrm{N} \leq 89)$, and very high $(90 \leq \mathrm{N} \leq 100)$. To measure the improvement of students'

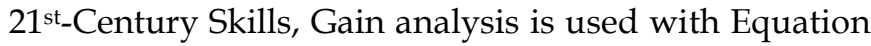
4.

$$
\langle g\rangle=\frac{\left\langle S_{\text {post }}\right\rangle-\left\langle S_{\text {pre }}\right\rangle}{100 \%-\left\langle S_{\text {pre }}\right\rangle}
$$

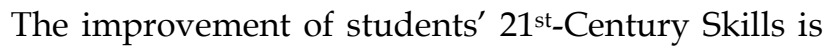
assessed based on three categories, namely low $(\mathrm{g}<0.3)$, moderate $(0.3<\mathrm{g}<0.7)$, and high $(\mathrm{g}>0.7)$.

\section{RESULTS AND DISCUSSION}

\section{The Conceptual Framework Design of the Online- based Inquiry Learning Model}

The conceptual design of the Online-based Inquiry learning model is based on the results of a literature review on constructivism learning theory, connectivism learning theory, learning model theory, inquiry-based learning theory, integration of ICT in learning, and 21 $1^{\text {st }}$ Century Skills framework. The design results are arranged into components of the learning model, as shown in Figure 1 and Figure 2. 


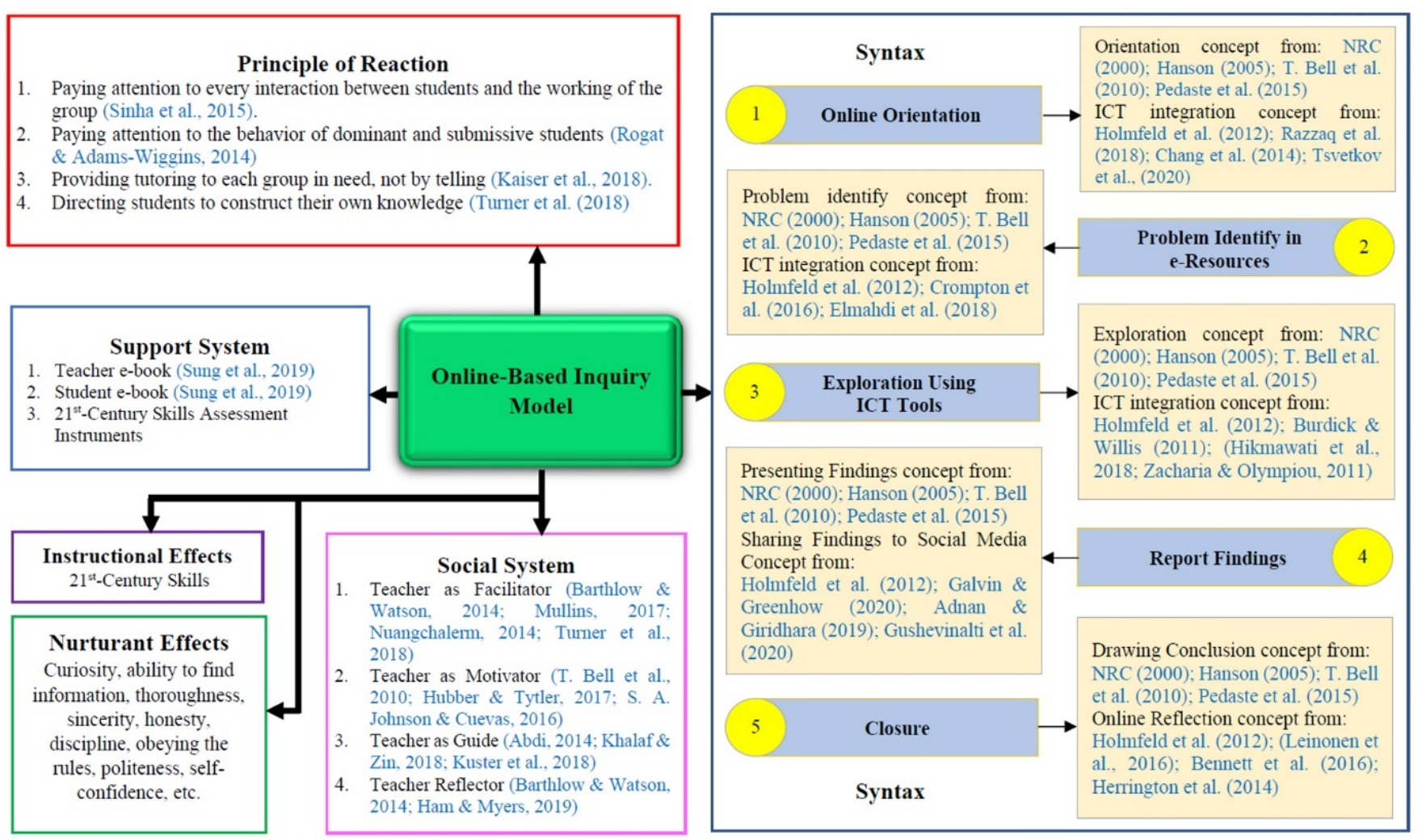

Figure 1. Conceptual design of online-based inquiry learning model

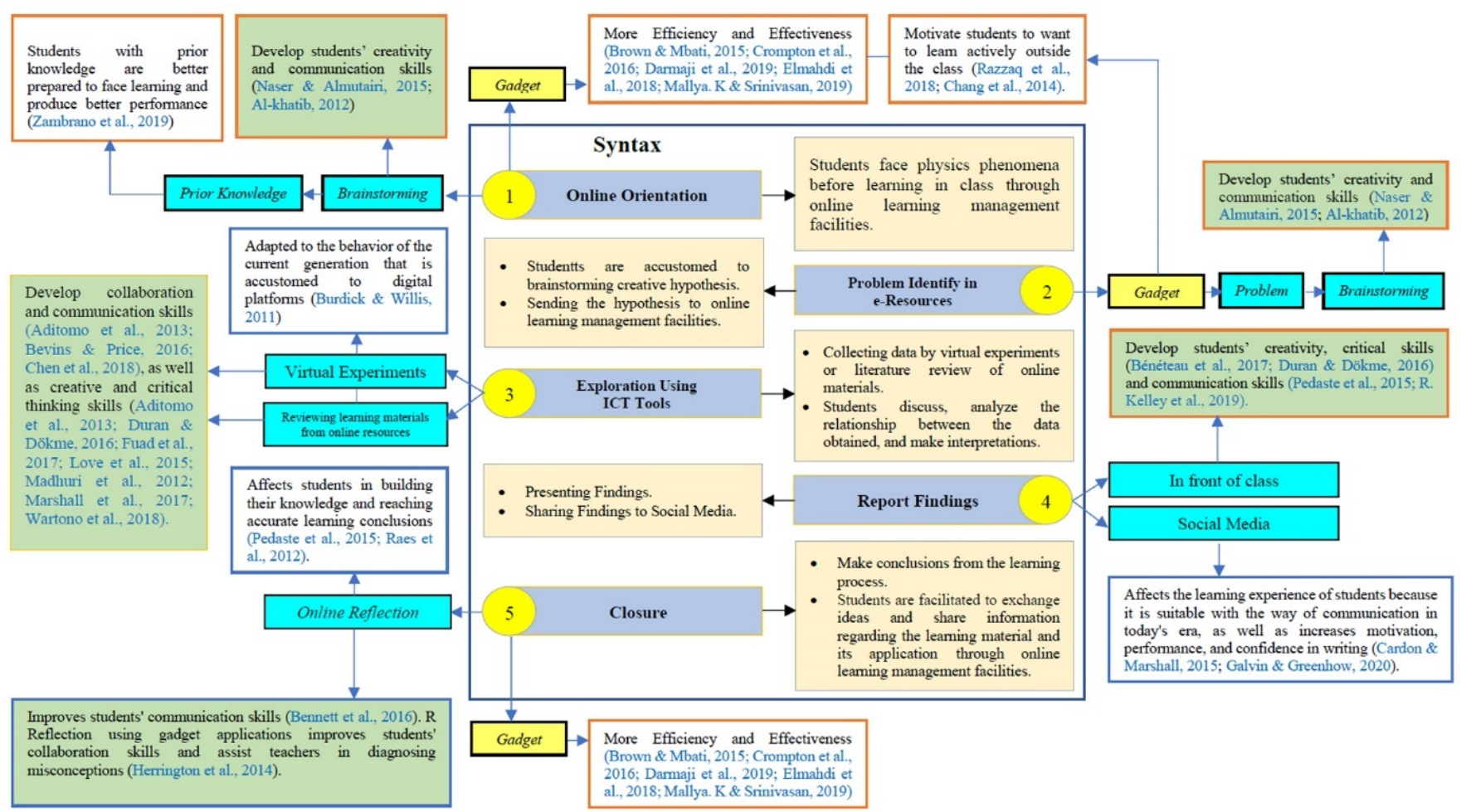

Figure 2. Scheme for the impact of learning model syntax on $21^{\text {st-century skills }}$

The position of the Online-based Inquiry learning model against other learning models and being state-ofthe-art in this research can be seen in Table 1.

Table 1 shows that the novelty of the Online-based Inquiry learning model syntax is the integration of ICT that accommodates the activities of students in each phase. The aim is to train creativity, critical thinking, collaboration, and communication skills integrated with ICT literacy to students. Furthermore, it also aims to overcome the problem of learning hours in the classroom, which did not have the ability to accommodate all the steps of the inquiry-based learning model previously. 
Table 1. Comparison of inquiry-based learning phases

\begin{tabular}{lllll}
\hline NRC (2000) & Hanson (2005) & T. Bell et al. (2010) & $\begin{array}{l}\text { Pedaste et al. (2015); Pedaste Online-based Inquiry } \\
\text { \& Mitt (2020) }\end{array}$ \\
\hline $\begin{array}{llll}\text { Oriented Questions: } \\
\text { Questioning Problems }\end{array}$ & $\begin{array}{l}\text { Orientation: } \\
\text { Providing } \\
\text { apperception and } \\
\text { motivation to students, } \\
\text { as well as conveying }\end{array}$ & $\begin{array}{l}\text { Orientation: } \\
\text { Questioning Problems }\end{array}$ & $\begin{array}{l}\text { Orientation: } \\
\text { Stimulating students' } \\
\text { curiosity on learning topics }\end{array}$ & $\begin{array}{l}\text { Online Orientation: } \\
\text { Facing a phenomenon to } \\
\text { students before learning } \\
\text { in the classroom through } \\
\text { online learning } \\
\text { management facilities. }\end{array}$ \\
& & & mangectives
\end{tabular}

\section{Develop explanations Exploration: \\ that address Presenting problems, \\ scientifically oriented formulating \\ questions: hypotheses, collecting \\ Creating a hypothesis data, testing \\ hypotheses}

Formulate explanations from

evidence:

Concept Formation:

Building and

presenting the

Making an explanation concepts found.

by comparing the

hypothesis with the

exploration results.

Evaluate explanations: Application:

Evaluating

explanations

Applying the built

knowledge to other

situations

$\begin{array}{ll}\text { Communicate: } & \text { Closure: } \\ \text { Communicating } & \text { Learning reflection }\end{array}$

inquiry results

\author{
Hypothesis \\ Generation

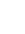

\section{Conceptualization: \\ - Questioning \\ - Hypothesis Generation}

Problem Identify in eResources:

- Questioning

- Sending Hypotheses

\section{Planning: \\ Planning the \\ exploration process \\ Investigation \\ - Exploration: \\ - Experimentation: \\ - Data Interpretation:}

\section{Investigation}

- Interpretation

- Conclusion

- Communication

- Prediction:

Applying the built

knowledge by

predicting the solution discussions

of the problem in other

situations results
Conclusion:

Making conclusions based on $\bullet$ Presenting Findings the comparison of

hypotheses and experimental •

Discussion:
- Communication
Presenting the findings
- Reflection
Evaluating the learning
process by conducting
discussions

\section{Exploration Using ICT}

Tools:

- Virtual Experiment or Reviewing learning materials from online resources

- Analyzing Data

- Explanations from Evidence

Report Findings: in Front of Class

Sharing Findings to Social Media

\author{
Closure: \\ - Drawing Conclusion \\ - Online Reflection: \\ Exchanging ideas, \\ sharing information, and \\ others regarding the \\ learning materials \\ studied and their \\ application after learning \\ through online learning \\ management facilities.
}

In the first syntax (Online Orientation), students face physics phenomena that cause intellectual confrontation and trigger their ability to brainstorm the phenomenon and develop their creativity and thinking skills. According to Naser and Almutairi (2015), and Al-khatib (2012), brainstorming enables students to be accustomed to expressing their opinions orally and in writing, thereby enhancing their communication skills.

Another aim of this first syntax is to make students have prior knowledge on the strategies needed to deal with learning in the classroom. According to Zambrano et al. (2019), students with prior knowledge are better prepared to face learning and produce better performance. Furthermore, the effectiveness of collaborative learning is strongly influenced by prior knowledge in achieving learning objectives (Liu et al., 2014; Zhang et al., 2016).
This first stage is carried out through student gadgets before learning in class. In addition to considerations of efficiency and effectiveness (Brown \& Mbati, 2015; Crompton et al., 2016; Darmaji et al., 2019; Elmahdi et al., 2018; Mallya. K \& Srinivasan, 2019), the use of gadgets, such as e-books connected with the Google Classroom application motivates students to prepare themselves before learning. According to Razzaq et al. (2018), gadgets motivate students to want to learn actively outside the class because the self-efficacy of technology affects their self-regulation. Students' self-efficacy of technology is a factor that affects their performance and motivation in an online environment (Chang et al., 2014). This process is a cognitive and an apperception model that combines an information approach with cognitive methods to build complex mental readiness (Tsvetkov et al., 2020). 
In the second syntax (Problem Identify in eResources), students are accustomed to brainstorming creative ideas to improve their communication skills. This is the initial stage of the core learning activities in the classroom. Furthermore, they are also faced with physics problems that aim to cause intellectual confrontation (confusion) and provide opportunities to formulate hypotheses. According to Bevins and Price (2016), Kabil (2015), and NRC (2013), problems in science learning, especially physics, are something that experts highly recommend. According to Psychologists Gestalt and Edward C. Tolman, when students are faced with problems, a state of cognitive disequilibrium appears and raises motivational elements (Hergenhahn \& Olson, 2017). In other words, students are motivated to determine an insight on the solution to the problem. This second stage is also accommodated by the efficiency and effectiveness of students' gadgets (Brown \& Mbati, 2015; Crompton et al., 2016; Darmaji et al., 2019; Elmahdi et al., 2018; Mallya. K \& Srinivasan, 2019). Therefore, gadgets, such as e-books connected to the Google Classroom application, accommodate the formulation of hypotheses from all students.

In the third syntax (Exploration Using ICT Tools), students perform exploration related to the problems presented in the second syntax, which is accommodated by their gadgets. Data collection is carried out by virtual experiments when the material is abstract or difficult to be observed, such as analyzing the pattern of changes in velocity values constantly within a certain period, analyzing patterns of constant changes in velocity values in a vertical motion, setting force values to analyze the relationship between acceleration, mass, and force. Furthermore, the data were collected through reviewing learning materials from online resources when the material is factual and does not require procedural analysis, such as the notion of position, distance, displacement, speed, velocity, acceleration, and force.

The application of virtual experiments and reviewing learning materials from online resources is based on the characteristics of current students. According to Burdick and Willis (2011), the learning approach needs to be adapted to the behavior of the current generation that is accustomed to digital platforms. Furthermore, the application of virtual experiments in physics learning shows results that are as effective as the application of real experiments in enhancing students' knowledge, attitudes, and skills competencies (Hikmawati et al., 2018; Zacharia \& Olympiou, 2011). The application of literature review is also very important because it is part of inquiry and affects students in building their knowledge and reaching accurate learning conclusions (Pedaste et al., 2015; Raes et al., 2012).

After collecting data, students discuss, analyze the relationship between the data obtained, and make interpretations. These activities train them to develop collaboration and communication skills (Aditomo et al.,
2013; Bevins \& Price, 2016; Boaventura et al., 2020; Chen et al., 2018), as well as creative and critical thinking skills (Aditomo et al., 2013; Duran \& Dökme, 2016; Fuad et al., 2017; Love et al., 2015; Madhuri et al., 2012; Marshall et al., 2017; Wartono et al., 2018). This is because, in this exploration process, students are accustomed to exploring, concluding, and discussing information, then presenting the results with deductive or inductive explanations and formal communication styles.

In the fourth syntax (Report Findings), students are allowed to convey their findings by interpreting the data obtained in the exploration process with the formulated hypothesis. The delivery of these findings is carried out through class presentations and by sharing them on social media. Apart from being part of the inquiry process that develops students' scientific skills (Duran \& Dökme, 2016; Love et al., 2015), presentations in front of the class helps to develop their critical, creative thinking (Bénéteau et al., 2017; Duran \& Dökme, 2016) and communication skills (Pedaste et al., 2015; R. Kelley et al., 2019). Currently, it is not mandatory to distribute these findings in front of the class due to the emergence of social media. Scientific facts show that today's society is more interested in the information presented on social media (Galvin \& Greenhow, 2020). This is important to use in education (Adnan \& Giridharan, 2019) because it can prevent students from the habit of using social media for unimportant things (Hagler, 2013). Furthermore, it is important to note that the current form of communication is digital because it goes both ways (Gushevinalti et al., 2020), and it is more open and broader (Galvin \& Greenhow, 2020; Hickerson \& Kothari, 2017). The delivery of learning findings on social media is necessary to prepare students to have communication skills relevant today. According to Cardon \& Marshall (2015) and Galvin \& Greenhow (2020), the use of social media in learning affects the learning experience of students because it is suitable with the way of communication in today's era, as well as increases motivation, performance, and confidence in writing.

The last stage in the Online-based Inquiry learning model is the fifth syntax (Closure), which consists of two main activities. Firstly, the teacher and students make conclusions from the learning process for proper evaluation and conclusion (Bevins \& Price, 2016; Pedaste et al., 2015). Secondly, after learning in class (online reflection), students are facilitated to exchange ideas and share information regarding the learning material and its application. This activity is carried out through student gadgets after learning due to the efficiency and effectiveness (Brown \& Mbati, 2015; Crompton et al., 2016; Darmaji et al., 2019; Elmahdi et al., 2018; Mallya. K \& Srinivasan, 2019), and motivation (Chang et al., 2014; Razzaq et al., 2018).

According to Leinonen et al. (2016), this activity is very important in learning using gadget applications 


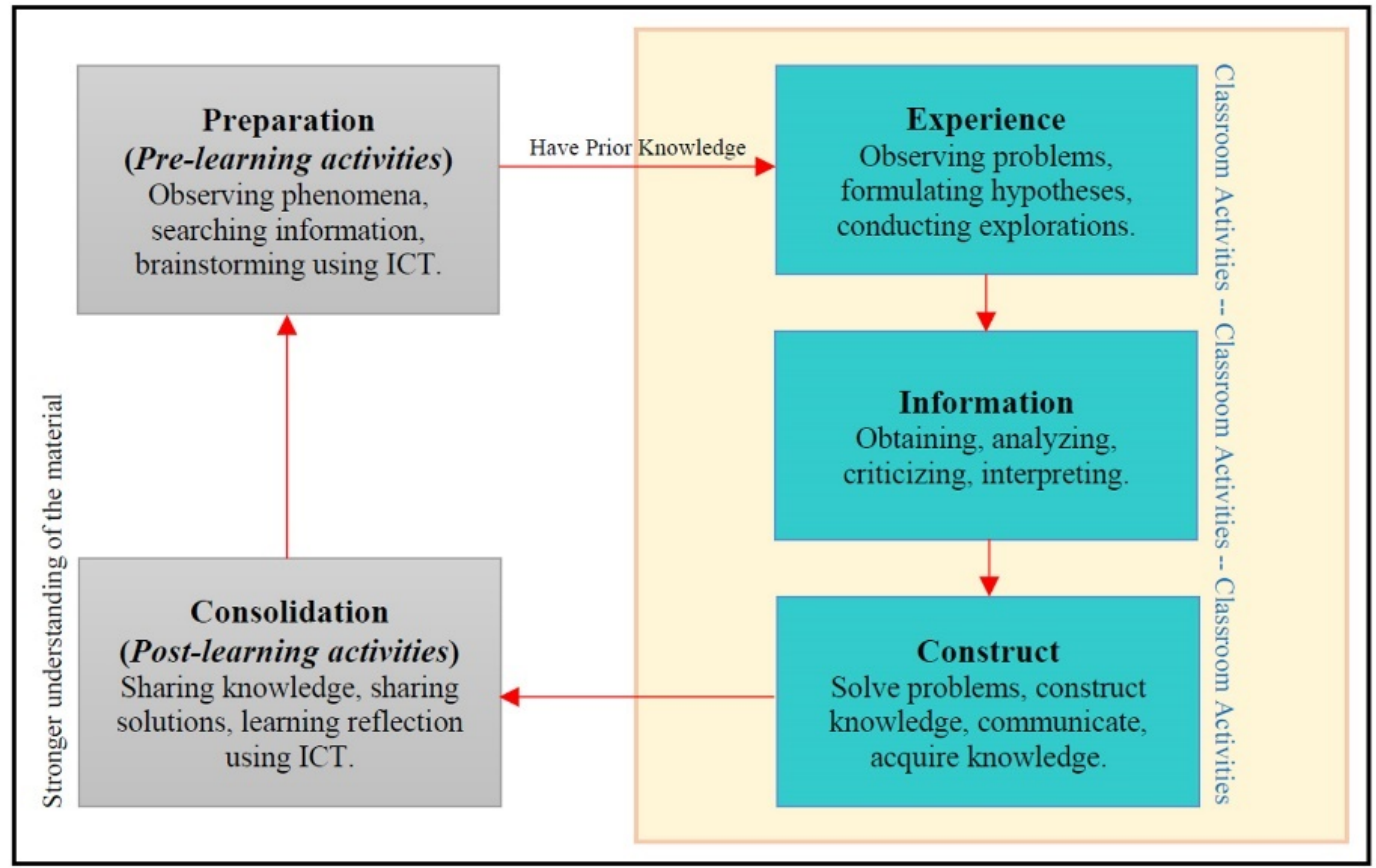

Figure 3. The basic cycle of online-based inquiry learning

because it provides benefits for students to ask questions, discuss, and work together in order to achieve a more complex level of knowledge outside the classroom. Reflection using gadget applications improves students' collaboration and communication skills (Bennett et al., 2016) and assists teachers in diagnosing misconceptions (Herrington et al., 2014). Moreover, student interaction level (discussion) in the digital group is higher than in the group without digital tools (Heindl, 2018). Therefore, this activity acts as a place for students to develop their creative and critical thinking, collaboration, and communication skills. The teacher also uses it as a tool for diagnosing misconceptions and determining the extent to which students develop learning materials.

This concept describes that the Online-based Inquiry learning model is an embodiment of learning that has a balance between a scientific approach and the use of technology to accommodate students in developing $21^{\text {st }}$ Century Skills and constructing their understanding through concrete and digital experiences. In its implementation, the Online-based Inquiry learning model phases are a cycle that includes preparation for prior knowledge, observing phenomena, gathering information, building and developing knowledge, as shown in Figure 3.

Online-based Inquiry learning has a systematic and comprehensive activity in discussing a lesson topic based on the process cycle. The existence of a preparation process to build students' prior knowledge provides better performance in the inquiry process in the classroom. Moreover, the existence of a reflection process after learning in class using online learning management facilities a more stable understanding of students. Furthermore, the Online-based Inquiry learning model also maximally involves students' thinking (creative, critical, systematic, analytical, and logical), scientific (scientific attitudes and skills), and social (communication and collaboration) abilities. Therefore, the process cycle of the Online-based Inquiry learning model is a solution to the development of students' $21^{\text {st_Century Skills. }}$

\section{The Validity of the Online-based Inquiry Learning Model}

The assessment included the validity of content, construct, and language. Product validation was carried out by five experts in written form and discussed until they agreed that the Online-based Inquiry learning model developed was valid, as shown in Table 2.

\section{The Practicality of the Online-based Inquiry Learning Model}

According to Plomp and Nieveen (2013), the practicality of the product developed (intervention) is seen from the ease of usage. The practicality of the Online-based Inquiry learning model is shown by the consistency between the typology of expectations with assessments and operations. This means that the practicality of the learning model is determined by the assessment of experts that stated that the product developed can be applied. In this case, it is known that the syntax, social system, and reaction principle of the Online-based Inquiry learning model according to the validators at the validation stage can be implemented with the average values of $\mathrm{V}$ at $0.83,0.75$, and 0.83 , respectively. Furthermore, these results are compared with the teacher and student responses regarding the 
Table 2. Product development validation results

\begin{tabular}{llcc}
\hline \multirow{2}{*}{ Product } & Component & \multicolumn{2}{c}{ Validity } \\
\cline { 2 - 3 } Model book & Construct & Score $(\mathrm{V})$ & Description \\
& Content & 0.91 & Very high \\
& Language & 0.85 & Very high \\
\hline Teacher e-book & Construct & 0.86 & Very high \\
& Content & 0.85 & Very high \\
& Language & 0.84 & Very high \\
\hline Student e-book & Construct & 0.86 & Very high \\
& Content & 0.89 & Very high \\
& Language & 0.91 & Very high \\
\hline 21st_Century Skills Assessment & Construct & 0.88 & Very high \\
& Content & 0.94 & Very high \\
& Language & 0.88 & Very high \\
\hline
\end{tabular}

Table 3. Practicality results according to teacher

\begin{tabular}{|c|c|c|c|}
\hline Assessment Aspect & SSHS 1 SP & SSHS 3 SP & SSHS 7 KR \\
\hline \multicolumn{4}{|l|}{ Teacher e-book } \\
\hline The ease of applying teacher e-book in physics learning. & 4 & 3.66 & 3.66 \\
\hline The usefulness of teacher e-book in physics learning. & 3.60 & 3.80 & 3.80 \\
\hline The usability of teacher e-book in physics learning. & 3.66 & 4 & 4 \\
\hline Average (\%) & 93.18 & 95.45 & 95.45 \\
\hline Overall Average (\%) & & 94.70 & \\
\hline Category & & Very Practical & \\
\hline \multicolumn{4}{|l|}{ Student e-book } \\
\hline The ease of following student e-book in physics learning. & 4 & 3.66 & 3.66 \\
\hline The usefulness of student e-book in physics learning & 3.83 & 4 & 3.83 \\
\hline The usability of student e-book in physics learning. & 3.60 & 4 & 3.80 \\
\hline Time allocation for the application of student e-book in physics learning. & 4 & 4 & 4 \\
\hline Average (\%) & 95.31 & 98.43 & 95.31 \\
\hline Overall Average (\%) & & 96.35 & \\
\hline Category & & Very Practical & \\
\hline
\end{tabular}

Table 4. Practicality results according to students

\begin{tabular}{|c|c|c|c|}
\hline Assessment Aspect & SSHS 1 SP & SSHS 3 SP & SSHS 7 KR \\
\hline The ease of following student e-book in physics learning. & 3.23 & 3.06 & 3.31 \\
\hline The usefulness of student e-book in physics learning. & 3.45 & 3.36 & 3.37 \\
\hline The usability of student e-book in physics learning. & 3.47 & 3.44 & 3.44 \\
\hline Time allocation for the application of student e-book in physics learning. & 3.65 & 3.56 & 3.51 \\
\hline Average $(\%)$ & 86.71 & 84.45 & 85.46 \\
\hline Overall Average (\%) & & 85.54 & \\
\hline Category & & Very Practica & \\
\hline
\end{tabular}

practicality of the Online-based Inquiry learning model actualized by the application of the teacher and student e-books. The practicality results according to the teacher are shown in Table 3.

Table 3 shows that the Online-based Inquiry learning model actualized with the teacher and student e-books is practical and makes it easier for teachers to convey the material of straight motion and Newton's laws. The average percentage of teacher and student e-books is in the 80-100 intervals and in a very practical category. Respondents consider that the learning model makes learning activities more practical for teachers and students. The model practicality results according to students are shown in Table 4.
Table 4 shows that the Online-based Inquiry learning model actualized with student e-book help facilitate students in the learning process. The average percentage of the assessment is in the 80-100 intervals, in a very practical category and more practical for students.

\section{The Effectiveness of the Online-based Inquiry Learning Model}

According to Plomp and Nieveen (2013), the effectiveness of the developed product (intervention) is seen from the achievement level of an expected goal. This means that the Online-based Inquiry learning model is declared effective when it has the ability to

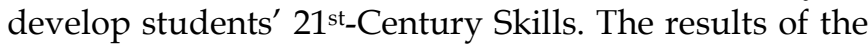
field test stage obtained from the three schools and the 
Table 5. $21^{\text {st }}$-century skills assessment results

\begin{tabular}{|c|c|c|c|c|c|}
\hline \multicolumn{6}{|c|}{ State Senior High School (SSHS) 1 Sungai Penuh } \\
\hline \multirow{2}{*}{ Observed aspects } & \multicolumn{5}{|c|}{ Meeting } \\
\hline & Pre-experiment & $\mathrm{I}$ & II & III & IV \\
\hline Creativity & 55.56 & 61.88 & 72.50 & 76.46 & 84.24 \\
\hline Critical thinking & 49.91 & 54.31 & 66.99 & 73.80 & 82.18 \\
\hline Collaboration & 70.93 & 77.13 & 82.59 & 85.00 & 87.96 \\
\hline Communication & 63.98 & 71.02 & 74.93 & 79.19 & 84.12 \\
\hline Average & 60.09 & 66.08 & 74.25 & 78.61 & 84.62 \\
\hline Category & Low & Adequate & Adequate & Adequate & High \\
\hline \multicolumn{6}{|c|}{ State Senior High School (SSHS) 3 Sungai Penuh } \\
\hline \multirow{2}{*}{ Observed aspects } & \multicolumn{5}{|c|}{ Meeting } \\
\hline & Pre-experiment & I & II & III & IV \\
\hline Creativity & 54.91 & 66.81 & 76.04 & 83.13 & 88.68 \\
\hline Critical thinking & 47.22 & 60.79 & 68.33 & 76.25 & 77.45 \\
\hline Collaboration & 72.87 & 77.13 & 81.02 & 86.76 & 90.00 \\
\hline Communication & 62.50 & 72.36 & 78.15 & 82.52 & 86.69 \\
\hline Average & 59.37 & 69.27 & 75.89 & 82.16 & 85.70 \\
\hline Category & Low & Adequate & Adequate & High & High \\
\hline \multicolumn{6}{|c|}{ State Senior High School (SSHS) 7 Kerinci } \\
\hline \multirow{2}{*}{ Observed aspects } & \multicolumn{5}{|c|}{ Meeting } \\
\hline & Pre-experiment & I & II & III & IV \\
\hline Creativity & 53.24 & 66.67 & 73.75 & 80.95 & 84.61 \\
\hline Critical thinking & 45.46 & 57.82 & 63.43 & 72.22 & 78.94 \\
\hline Collaboration & 70.74 & 70.46 & 75.00 & 85.19 & 88.61 \\
\hline Communication & 61.94 & 67.57 & 72.45 & 80.35 & 83.17 \\
\hline Average & 57.84 & 65.63 & 71.15 & 79.67 & 83.83 \\
\hline Category & Low & Adequate & Adequate & Adequate & High \\
\hline
\end{tabular}

Table 6. $21^{\text {st-century skill N-gain score }}$

\begin{tabular}{lccccc}
\hline \multirow{2}{*}{ School } & \multicolumn{3}{c}{ N-Gain Score } & Average \\
\cline { 2 - 5 } & Creativity & Critical Thinking & Collaboration & Communication & 0.56 \\
SSHS 1 SP & 0.65 & 0.62 & 0.64 & 0.64 & 0.62 \\
SSHS 3 SP & 0.74 & 0.55 & 0.69 & 0.56 & 0.65 \\
SSHS 7 KR & 0.67 & 0.60 & 0.63 & 0.63 & 0.61 \\
\hline Average & \multicolumn{5}{c}{ Moderate } \\
\hline Category & \multicolumn{5}{c}{}
\end{tabular}

analysis of their improvement indicate that students experience an increase in each meeting, as shown in Table 5 and Table 6.

At the first meeting, the average scores of $21^{\text {st }}$ Century Skills at State Senior High Schools 1 Sungai Penuh, 3 Sungai Penuh, and 7 Kerinci are 66.08, 69.27, and 65.63, respectively. Sub-evaluations that are still classified in the low category are creative and critical thinking skills. However, the score of creative thinking skills at State Senior High Schools 3 Sungai Penuh and 7 Kerinci is in the adequate category of 66.81 and 66.67. In comparison, State Senior High School 1 Sungai Penuh is still relatively low at 61.88 . This is because the mental readiness and self-confidence of students are still low in expressing their opinions. According to Chan (2013), an important factor for fluency in expressing opinions is self-confidence. The courage and confidence of students to express opinions depend on their mental readiness (Sullivan, 2015). These two factors are very important to make students able to express their opinions fluently.
Furthermore, the score of critical thinking skills at State Senior High Schools 1 Sungai Penuh, 3 Sungai Penuh, and 7 Kerinci are 54.31, 60.79, and 57.82, which are still in the low category. This is because of the previous class culture factors that accustom students to accept the opinions of others without discussions. According to Ghadi et al. (2012), and Facione and Gittens (2013), the culture of seeking truth, open-mindedness, confidence, and curiosity in the classroom are important factors that influence the development of students' critical thinking skills. In other words, poor teacherstudent interaction (class culture) can constrain the implementation of dialogic learning (Worku \& Alemu, 2021).

At the next meeting, the average scores of $21^{\text {st }}$ Century Skills at State Senior High Schools 1 Sungai Penuh, 3 Sungai Penuh, and 7 Kerinci are 74.25, 75.89, and 71.15 respectively. All sub-evaluations are in the adequate category, with none in the low category. This increase indicates that students are getting used to the Online-based Inquiry learning model. The complexity of the learning model, which is at the Guided Inquiry level, 
also has a positive effect because Guided Inquiry can be used on students that do not have much learning experience with inquiry steps (Lazonder \& Harmsen, 2016), and the teacher does not lose control to provide better learning experiences for students (Bodner \& Elmas, 2021).

Creative and critical thinking skills, which were initially low at the first meeting, reached adequate category at this meeting. This indicates that the problem of the previous class culture that accustoms students to accept other people's opinions without the desire to determine and discuss the process can be overcome. This shows that gadgets in the first syntax motivate students to prepare themselves before learning. According to Razzaq et al. (2018), gadgets provide intrinsic motivation for students to learn outside the classroom actively. Therefore, students have prior knowledge to deal with learning in the classroom. Hence, they are more confident to argue and provide feedback on the opinions of their peers.

One sub-evaluation that reached a high category at this second meeting is collaboration. This achievement is in State Senior High School 1 Sungai Penuh and 3 Sungai Penuh, with scores of 82.59 and 81.02, respectively. Meanwhile, in the State Senior High School 7 Kerinci is still in the adequate category of 75.00 . The achievement is due to the arrangement of activities in the Onlinebased Inquiry learning model that creates positive social interactions among students, such as collecting data, analyzing the relationship, and making interpretations for solving problems. This interaction creates a positive dependence between group members to rely on each other, leading to trust and responsibility (Kwon et al., 2013; Laal, 2013; Patel et al., 2012). Moreover, the prior knowledge factor makes their collaborative performance better (Zambrano et al., 2019).

In contrast to State Senior High School 1 Sungai Penuh and 3 Sungai Penuh, collaboration skills at State Senior High School 7 Kerinci have not yet reached the high category. This is because the teachers divided the groups based on the order of absent numbers, hence their composition was not heterogeneous. According to Lai (2011), teachers need to pay attention to group composition in terms of students' gender and ability level to make the application of group learning able to produce better student collaboration performance. However, gender did not significantly affect the collaboration performance of students (De Hei et al., 2015). This is proven in the State Senior High School 1 Sungai Penuh, where three non-heterogeneous groups showed good collaboration performance.

Furthermore, at the third and fourth meetings, the average score of $21^{\text {st }}$ Century Skills at State Senior High Schools 1 Sungai Full, 3 Sungai Penuh, and 7 Kerinci increased by $78.61,82.16$, and 79.67 at the third meeting and $84.62,85.70$, and 83.83 at the fourth. The results of the three schools are already in the high category. However, among the four sub-evaluations, students' critical thinking skills at State Senior High Schools 3 Sungai Penuh and 7 Kerinci are still in the adequate category with an average of 77.45 and 78.94 respectively. In terms of critical thinking skills sub-evaluation indicators, the ability to evaluate other people's arguments has the lowest score compared to other indicators, thereby affecting the average achievement of the sub-evaluation. This is because this indicator is very conditional where the ability to evaluate other people's arguments is only determined when there is a misconception among students. However, based on the improvement, critical thinking skills at State Senior High Schools 1 Sungai Penuh and 7 Kerinci have better NGain scores than communication skills. This indicates that Online-based Inquiry learning model is able to have a positive influence on the development of students' critical thinking skills.

The results obtained from four meetings at the three schools indicated that creative thinking and communication skill sub-evaluations do not show a significant anomaly. In all syntaxes, the Online-based Inquiry learning model accommodates the development of the two sub-evaluations. Students carry out brainstorming in the first and second syntax, which improves their creativity and communication skills (Alkhatib, 2012; Naser \& Almutairi, 2015). In the third syntax, students collected data, analyzed the relationship, and made interpretations. These activities train them to develop communication skills (Aditomo et al., 2013; Bevins \& Price, 2016; Chen et al., 2018) and creative thinking skills (Aditomo et al., 2013; Duran \& Dökme, 2016; Fuad et al., 2017; Love et al., 2015; Madhuri et al., 2012; Marshall et al., 2017; Wartono et al., 2018).

In the fourth syntax, students conveyed their findings through classroom presentations to develop critical and creative thinking (Bénéteau et al., 2017; Duran \& Dökme, 2016) and communication skills (Pedaste et al., 2015; R. Kelley et al., 2019). Furthermore, in the fifth syntax, online reflection provided an opportunity for students to ask questions and express opinions. This activity improves their communication (Bennett et al., 2016) and creative thinking skills (Duran \& Dökme, 2016).

Overall, the four sub-evaluations of students' $21^{\text {st }}$ Century Skills experience a significant increase with NGain scores above 0.50 in the three schools. The average N-Gain scores at State Senior High Schools 1 Sungai Penuh, 3 Sungai Penuh, and 7 Kerinci are 0.62, 0.65, and 0.61 , respectively, and in the moderate category. These results indicate that the Online-based Inquiry learning

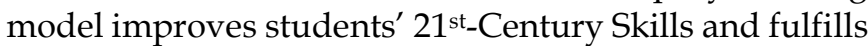
the third intervention quality criteria as an effective learning model. 


\section{LIMITATIONS}

Although the present Online-based Inquiry learning model seems effective, there are several limitations to this research. First, the sample size was not large. To better understand the effect of the model, large-scale experiments are needed in future research. Future research also needs to examine more deeply the effect of the Online-based Inquiry learning model at all levels of education, namely elementary, junior high school, and college levels. Second, the effectiveness assessment did not control for factors outside the research variables, such as physical condition, intelligence, and background of students, and teacher competence. Analysis of Covariance (ANCOVA) is needed to assess its effectiveness in future research.

\section{IMPLICATIONS}

The findings contribute to teachers' practice in designing lessons capable of improving students' $21^{\text {st }}$ Century Skills in physics learning and other fields of science and become an option for promoting learning in accordance with the students' characteristics (digital native) and trends $21^{\text {st_Century learning. This research }}$ provides evidence that a model that has a balance between the scientific approach and the use of technology is relevant model to be applied today, especially in the New Normal COVID-19 era in Indonesia, and being a bridge to the digitalization of Indonesian education in the future.

\section{CONCLUSION}

In conclusion, the Online-based Inquiry learning model has a high quality in terms of validity, practicality, and effectiveness. The validity results of model book, teacher e-book, student e-book, and 21st-Century Skills assessment are in very high validity criteria in terms of content, construct, and language. This means that the learning model has fulfilled the criteria of relevance and consistency. According to teachers and students, the use of Online-based Inquiry learning model fulfills the criteria of ease, usefulness, and usability. In terms of effectiveness, the learning model is able to improve the

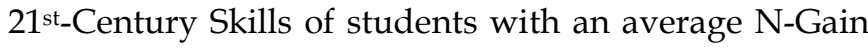
score of 0.63 . In other words, Online-based Inquiry learning model has a significant influence on the

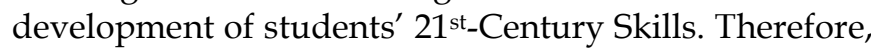
it can be used by physics teachers and those in other science fields to improve the quality of learning and

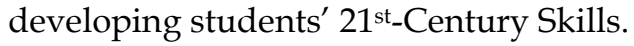

\footnotetext{
Author contributions: All authors have sufficiently contributed to the study, and agreed with the results and conclusions.

Funding: This research was supported by the funding program for the Doctoral Dissertation Research of the Republic of Indonesia Ministry of Education and Culture.

Declaration of interest: No conflict of interest is declared by authors.
}

\section{REFERENCES}

AASL. (2019). Standards for the 21st century learner. American Association of School Library. https: / / www.ala.org/tools/research/librariesmat ter/standards-21st-century-learner

Aditomo, A., \& Klieme, E. (2020). Forms of inquirybased science instruction and their relations with learning outcomes: evidence from high and lowperforming education systems. International Journal of Science Education, 42(4), 504-525. https:/ / doi.org/10.1080/09500693.2020.1716093

Aditomo, A., Goodyear, P., Bliuc, A. M., \& Ellis, R. A. (2013). Inquiry-based learning in higher education: Principal forms, educational objectives, and disciplinary variations. Studies in Higher Education, 38(9), 1239-1258. https://doi.org/10.1080/ 03075079.2011.616584

Adnan, M., \& Anwar, K. (2020). How students' perspectives about online learning amid the COVID-19 pandemic? Studies in Learning and Teaching, 1(3), 133-139. https://doi.org/10.46627/ silet.v1i3.46

Adnan, M., \& Giridharan, B. (2019). Use of social media applications in classroom: Analysis from education perspective. IOP Conference Series: Materials Science and Engineering, 495(1), 012108. https://doi.org/ 10.1088/1757-899X/495/1/012108

Ahonen, A. K., \& Kinnunen, P. (2015). How do students value the importance of twenty-first century skills? Scandinavian Journal of Educational Research, 59(4), 395-412. https://doi.org/10.1080/00313831.2014. 904423

Al-khatib, A. (2012). The effect of using brainstorming strategy in developing creative problem solving skills among female students in Princess Alia University College. American International Journal of Contemporary Research, 2(10), 29-38. https://www.aijcrnet.com/journals/Vol_2_No_1 0_October_2012/4.pdf

Arends, R. I. (2009). Learning to teach (9th Ed.). McGrawHill, Inc.

Arikunto, S. (2015). Prosedur penelitian: Suatu pendekatan praktik [Research Procedure: A Practical Approach]. Rineka Cipta.

Asrizal, Amran, A., Ananda, A., Festiyed, F., \& Sumarmin, R. (2018). The development of integrated science instructional materials to improve students' digital literacy in scientific approach. Jurnal Pendidikan IPA Indonesia, 7(4), 442450. https:// doi.org/10.15294/jpii.v7i4.13613

Ayvaz Tunç, Ö. (2017). Material development based on digital storytelling activities and assessment of students' views. International Journal of Evaluation 
and Research in Education (IJERE), 6(1), 54. https://doi.org/10.11591/ijere.v6i1.6347

Azwar, S. (2014). Metode penelitian [Research methods]. Pustaka Pelajar.

Ball, A., Joyce, H. D., \& Anderson-Butcher, D. (2016). Exploring 21st century skills and learning environments for middle school youth. International Journal of School Social Work, 1(1), 1-15. https:/ / doi.org/10.4148/2161-4148.1012

Bell, T., Urhahne, D., Schanze, S., \& Ploetzner, R. (2010). Collaborative inquiry learning: Models, tools, and challenges. International Journal of Science Education, 32(3), 349-377. https://doi.org/10.1080/ 09500690802582241

Bénéteau, C., Guadarrama, Z., Guerra, J. E., Lenz, L., Lewis, J. E., \& Straumanis, A. (2017). POGIL in the calculus classroom. Primus, 27(6), 579-597. https:// doi.org/10.1080/10511970.2016.1233159

Bennett, D., Power, A., Thomson, C., Mason, B., \& Bartleet, B. L. (2016). Reflection for learning, learning for reflection: Developing indigenous competencies in higher education. Journal of University Teaching and Learning Practice, 13(2), 1-19. https://ro.uow.edu.au/jutlp/vol13/iss2/7

Bernhardt, P. E. (2015). 21st century learning: Professional development in practice. Qualitative Report, 20(1), 1-19. https://nsuworks.nova.edu/ tqr/vol20/iss1/1

Bevins, S., \& Price, G. (2016). Reconceptualising inquiry in science education. International Journal of Science Education, 38(1), 17-29. https://doi.org/10.1080/ 09500693.2015.1124300

Binkley, M., Erstad, O., Herman, J., Raizen, S., Ripley, M., Miller-Ricci, M., \& Rumble, M. (2012). Defining twenty-first century skills. In P. Griffin, B. McGaw, \& E. Care (Eds.), Assessment and teaching of 21st century skills (pp. 17-66). Springer. https:/ / doi.org/10.1007/978-94-007-2324-5

Boaventura, D., Faria, C., \& Guilherme, E. (2020). Impact of an inquiry-based science activity about climate change on development of primary students' investigation skills and conceptual knowledge. Interdisciplinary Journal of Environmental and Science Education, 16(4), e2225. https://doi.org/10.29333/ ijese/ 8554

Bodner, G., \& Elmas, R. (2021). The impact of inquirybased, group-work approaches to instruction on both students and their peer leaders. European Journal of Science and Mathematics Education, 8(1), 5166. https:// doi.org/10.30935/scimath/9546

Boyaci, D. B., \& Atalay, N. (2016). A scale development for 21st century skills of primary school students: A validity and reliability study. Applied Measurement in Education, 9(1), 1694609. https://doi.org/ 10.12973/iji.2016.9111a
Brown, T. H., \& Mbati, L. S. (2015). Mobile learning: Moving past the myths and embracing the opportunities. International Review of Research in Open and Distributed Learning, 16(2), 115-135. https://doi.org/10.19173/irrodl.v16i2.2071

Burdick, A., \& Willis, H. (2011). Digital learning, digital scholarship and design thinking. Design Studies, 32(6), 546-556. https://doi.org/10.1016/j.destud. 2011.07.005

Burgin, S. R. (2020). A three-dimensional conceptualization of authentic inquiry-based practices: a reflective tool for science educators. International Journal of Science Education, 42(9), 14651484.

https:/ / doi.org/10.1080/09500693.2020.1766152

Calmer, J. M. (2019). Teaching physics within a next generation science standards perspective. Pedagogical Research, 4(4), em0041. https:/ / doi.org/ $10.29333 / \mathrm{pr} / 5868$

Cardon, P. W., \& Marshall, B. (2015). The hype and reality of social media use for work collaboration and team communication. International Journal of Business Communication, 52(3), 273-293. https:/ / doi.org/10.1177/2329488414525446

Chan, Z. C. Y. (2013). A systematic review of creative thinking/creativity in nursing education. Nurse Education Today, 33(11), 1382-11387. https://doi.org/10.1016/j.nedt.2012.09.005

Chang, C. S., Liu, E. Z. F., Sung, H. Y., Lin, C. H., Chen, N. S., \& Cheng, S. S. (2014). Effects of online college student's Internet self-efficacy on learning motivation and performance. Innovations in Education and Teaching International, 51(4), 366-377. https:// doi.org/10.1080/14703297.2013.771429

Chen, J., Wang, M., Grotzer, T. A., \& Dede, C. (2018). Using a three-dimensional thinking graph to support inquiry learning. Journal of Research in Science Teaching, 55(9), 1239-1263. https:// doi.org/ 10.1002/tea. 21450

Choy, D., Deng, F., Chai, C. S., Koh, H. L. J., \& Tsai, P. S. (2016). Singapore primary and secondary students' motivated approaches for learning: A validation study. Learning and Individual Differences, 45, 282290. https://doi.org/10.1016/j.lindif.2015.11.019

Crompton, H., Burke, D., Gregory, K. H., \& Gra, C. (2016). The use of mobile learning in science: A systematic review. Journal of Science Education and Technology, 25, 149-160. https://doi.org/10.1007/ s10956-015-9597-x

Darmaji, Kurniawan, D. A., Astalini, Lumbantoruan, A., \& Samosir, S. C. (2019). Mobile learning in higher education for the industrial revolution 4.0: Perception and response of physics practicum. International Journal of Interactive Mobile Technologies, 13(09), 4-20. https://online-journals. 
org/index.php/i-jim/article/download/10948/ 5887

De Hei, M. S. A., Strijbos, J. W., Sjoer, E., \& Admiraal, W. (2015). Collaborative learning in higher education: lecturers' practices and beliefs. Research Papers in Education, 30(2), 232-247. https:/ / doi.org/10.1080/ 02671522.2014 .908407

Dhawan, S. (2020). Online learning: A panacea in the time of COVID-19 crisis. Journal of Educational Technology Systems, 49(1), 5-22. https://doi.org/ $10.1177 / 0047239520934018$

Donovan, L., Green, T. D., \& Mason, C. (2014). Examining the 21st century classroom: Developing an innovation configuration map. Journal of Educational Computing Research, 50(2), 161-178. https: / / doi.org/10.2190/EC.50.2.a

Duran, M., \& Dökme, I. (2016). The effect of the inquirybased learning approach on student's criticalthinking skills. Eurasia Journal of Mathematics, Science and Technology Education, 12(12), 2887-2908. https: / / doi.org/10.12973/ eurasia.2016.02311a

Dwianto, A., Wilujeng, I., Prasetyo, Z. K., \& Suryadarma, I. G. P. (2017). Designa implementation of schoology-based blended learning media for basic Physics I course. Jurnal Pendidikan IPA Indonesia, 6(1), 23-31. https:/ / doi.org/10.15294/jpii.v6i1.7205

Elmahdi, I., Al-Hattami, A., \& Fawzi, H. (2018). Using technology for formative assessment to improve students' learning. Turkish Online Journal of Educational Technology - TOJET, 17(2), 182-188. https:/ / files.eric.ed.gov/fulltext/EJ1176157.pdf

Facione, P., \& Gittens, C. (2013). Think critically (2nd ed.). Pearson. https://www.pearson.com/us/highereducation/program/Facione-THINK-Critically2nd-Edition/PGM229296.html

Fuad, N. M., Zubaidah, S., Mahanal, S., \& Suarsini, E. (2017). Improving junior high schools' critical thinking skills based on test three different models of learning. International Journal of Instruction, 10(1), 101-116. https:/ / doi.org/10.12973/iji.2017.1017a

Furtak, E. M., \& Penuel, W. R. (2019). Coming to terms: Addressing the persistence of "hands-on" and other reform terminology in the era of science as practice. Science Education, 103(1), 167-186. https://doi.org/10.1002/sce.21488

Galvin, S., \& Greenhow, C. (2020). Writing on social media: A review of research in the high school classroom. TechTrends, 64(1), 57-69. https:/ / doi.org /10.1007/s11528-019-00428-9

Ghadi, I., Alwi, N. H., Abu Bakar, K., \& Talib, O. (2012). Construct validity examination of critical thinking dispositions for undergraduate students in University Putra Malaysia. Higher Education Studies, 2(2), 138-145. https://doi.org/10.5539/hes.v2n2 p138
Gilbert, J. K., \& Justi, R. (2016). Analogies in modellingbased teaching and learning. https://doi.org/ 10.1007/978-3-319-29039-3_8

Gushevinalti, G., Suminar, P., \& Sunaryanto, H. (2020). Transformasi Karakteristik Komunikasi Di Era Konvergensi Media [Transformation of Communication Characteristics in the Age of Media Convergence]. Bricolage: Jurnal Magister Ilmu Komunikasi, 6(01), 083. https://doi.org/10.30813/ bricolage.v6i01.2069

Hagler, B. E. (2013). Value of social media in today's classroom. The Journal of Research in Business Education, 55(1), 14-23. https:/ / www.homeworkfor you.com/static_media/uploadedfiles/artical.pdf

Hanson, D. M. (2005). Designing process-oriented guidedinquiry activities. Stony Brook University.

Heindl, M. (2018). Inquiry-based Learning and its Possibilities for Primary Schools with fewer Digital Resources - A Qualitative Study. Pedagogical Research, 3(3), 1-8. https://doi.org/10.20897/pr/ 3932

Hergenhahn, B. R., \& Olson, M. H. (2017). Theories of learning (7th Ed.). Kencana.

Herrington, J., Parker, J., \& Boase-Jelinek, D. (2014). Connected authentic learning: Reflection and intentional learning. Australian Journal of Education, 58(1), 23-35. https://doi.org/10.1177/00049441135 17830

Hickerson, A., \& Kothari, A. (2017). Learning in public: Faculty and student opinions about social media in the classroom. Journalism and Mass Communication Educator, 72(4), 397-409. https://doi.org/10.1177/ 1077695816660639

Hikmawati, Kusmiyati, Sutrio, Kurniawan, E., \& Sakdiyah, H. (2018). Implementasi Metode Real Experiments dan Virtual Experiments pada Pembelajaran Fisika di SMAN 1 Kediri [Implementation of Real Experiments and Virtual Experiments Methods in Physics Learning at SSHS 1 Kediri]. Jurnal Pendidikan Fisika Dan Teknologi, 4(2), 185-191. https://jurnalfkip.unram.ac.id/ index.php/JPFT/article/view/814/pdf

Joyce, B., Weil, M., \& Calhoun, M. (2016). Models of teaching (9th Ed.). Pustaka Pelajar. https:/ / pustakapelajar.co.id/buku/models-ofteaching-edisi-ke-9/

Kabil, O. (2015). Philosophy in physics education. 7th World Conference on Educational Sciences, 197, 675679. https:/ / doi.org/10.1016/j.sbspro.2015.07.057

Kelley, T. R., Geoff Knowles, J., Han, J., \& Sung, E. (2019). Creating a 21st century skills survey instrument for high school students. American Journal of Educational Research, 7(8), 583-590. https://doi.org/10.12691/ education-7-8-7 
Kwon, K., Hong, R. Y., \& Laffey, J. M. (2013). The educational impact of metacognitive group coordination in computer-supported collaborative learning. Computers in Human Behavior, 29(4), 12711281. https://doi.org/10.1016/j.chb.2013.01.003

Laal, M. (2013). Positive interdependence in collaborative learning. 3rd World Conference on Learning, Teaching and Educational Leadership (WCLTA-2012), 93, 14331437. https:/ / doi.org/10.1016/j.sbspro.2013.10.058

Lai, E. (2011). Collaboration: A literature review research report. Pearson. http:/ / images.pearsonassessments. com/images/tmrs/collaboration-review.pdf

Lazonder, A. W., \& Harmsen, R. (2016). Meta-analysis of inquiry-based learning: Effects of guidance. Review of Educational Research, 86(3), 681-718. https:/ / doi.org/10.3102/0034654315627366

Leinonen, T., Keune, A., Veermans, M., \& Toikkanen, T. (2016). Mobile apps for reflection in learning: A design research in K-12 education. British Journal of Educational Technology, 47(1), 184-202. https://doi.org/10.1111/bjet.12224

Liu, T. C., Lin, Y. C., \& Paas, F. (2014). Effects of prior knowledge on learning from different compositions of representations in a mobile learning environment. Computers and Education, 72, 328-338.

https://doi.org/10.1016/j.compedu.2013.10.019

Love, B., Hodge, A., Corritore, C., \& Ernst, D. C. (2015). Inquiry-based learning and the flipped classroom model. Problems, Resources, and Issues in Mathematics Undergraduate Studies, 25(8), 745-762. https://doi.org/10.1080/10511970.2015.1046005

Madhuri, G. V., Kantamreddi, V. S. S. N., \& Prakash Goteti, L. N. S. (2012). Promoting higher order thinking skills using inquiry-based learning. European Journal of Engineering Education, 37(2), 117 123.

https:/ / doi.org/10.1080/03043797.2012.661701

Mallya. K, R., \& Srinivasan, B. (2019). Impact of mobile learning in the cloud on learning competencies of engineering students. International Journal of Biomedical Engineering (IJOE), 15(09), 80-87. https: / / doi.org/10.3991/ijoe.v15i09.10671

Marshall, J. C., Smart, J. B., \& Alston, D. M. (2017). Inquiry-based instruction: A possible solution to improving student learning of both science concepts and scientific practices. International Journal of Science and Mathematics Education, 15(5), 777-796. $\quad$ https://doi.org/10.1007/s10763-0169718-x

Muliyati, D., Herga Marizka, \& Bakri, F. (2019). Elearning using Wordpress on physics materials with the 5E learning cycle strategy. Jurnal Penelitian $\mathcal{E}$ Pengembangan Pendidikan Fisika, 5(2), 101-112. https:// doi.org/10.21009/1.05205
Naser, A., \& Almutairi, M. (2015). The effect of using brainstorming strategy in developing creative problem solving skills among male students in Kuwait: A field study on Saud Al-Kharji School in Kuwait City. Journal of Education and Practice, 6(3), 136-146 https:/ / files.eric.ed.gov/fulltext/EJ1083780.pdf

NRC. (2000). Inquiry and the National Science Education Standards. The National Academies Press. https:/ / doi.org/10.17226/9596

NRC. (2013). Education for life and work: Developing transferable knowledge and skills in the 21st century. National Academies. https://doi.org/10.17226/ 13398

Nurhasanah, N., Jumadi, J., Herliandry, L. D., Zahra, M., \& Suban, M. E. (2020). Perkembangan penelitian literasi sains dalam pembelajaran fisika di Indonesia [The Development of Scientific Literacy Research in Physics Learning in Indonesia]. Edusains, 12(1), 3846. https:/ / doi.org/10.15408/es.v12i1.14148

Partnership for 21st Century. (2019). Framework for 21st century learning definitions. https://www.battelle forkids.org/networks/p21/frameworks-resources

Patel, H., Pettitt, M., \& Wilson, J. R. (2012). Factors of collaborative working: A framework for a collaboration model. Applied Ergonomics, 43(1), 1-26. https: / / doi.org/10.1016/j.apergo.2011.04.009

Pedaste, M., \& Mitt, G. (2020). Framework for contemporary inquiry-based augmented reality learning. Proceedings - IEEE 20th International Conference on Advanced Learning Technologies, ICALT 2020, 327-328. https://doi.org/10.1109/ICALT 49669.2020.00105

Pedaste, M., Mäeots, M., Siiman, L. A., de Jong, T., van Riesen, S. A. N., Kamp, E. T., Manoli, C. C., Zacharia, Z. C., \& Tsourlidaki, E. (2015). Phases of inquiry-based learning: Definitions and the inquiry cycle. Educational Research Review, 14, 47-61. https://doi.org/10.1016/j.edurev.2015.02.003

Plomp, T., \& Nieveen, N. (2013). Educational design research: An introduction. SLO. https://slo.nl/ publish/pages/2904/educational-designresearch-part-a.pdf

Raes, A., Schellens, T., De Wever, B., \& Vanderhoven, E. (2012). Scaffolding information problem solving in web-based collaborative inquiry learning. Computers and Education, 59(1), 82-94. https://doi.org/10.1016/j.compedu.2011.11.010

Razzaq, A., Samiha, Y. T., \& Anshari, M. (2018). Smartphone habits and behaviors in supporting students self-efficacy. International Journal of Emerging Technologies in Learning (IJET), 13(02), 94109. https:// online-journals.org/index.php/ijet/article/download/7685/4794 
Reigeluth, C. M., Beatty, B. J., \& Myers, R. D. (2016). Instructional-design theories and models (Vol. 4). Routledge. https://doi.org/10.4324/9781315795478

Riduwan. (2009). Variabel-variabel penelitian [Research variables]. Alfabeta.

Sullivan, S. L. (2015). Student autonomy through creativity. The Journal of Literature in Language Teaching, 4(1), 35-53. http://liltsig.org/wpcontent/uploads/2015/07/LiLT_4_1_Sullivan.pdf

Syukri, M., Yanti, D. A., Mahzum, E., \& Hamid, A. (2021). Development of a PjBL model learning program plan based on a STEM approach to improve students' science process skills. Jurnal Penelitian Pendidikan IPA, 7(2), 269. https:// doi.org/10.29303/jppipa.v7i2.680

Tompo, B., Ahmad, A., \& Muris, M. (2016). The development of discovery-inquiry learning model to reduce the science misconceptions of junior high school students. International Journal of Environmental and Science Education, 11(12), 56765686.

https:// files.eric.ed.gov/fulltext/EJ1115682.pdf

Tsvetkov, V. Y., Rogov, I. E., Kozlov, A. V, \& Titov, E. K. (2020). The apperception of information in cognitive analysis. Journal of Physics: Conference Series, 1679, 032071. https:/ / doi.org/10.1088/17426596/1679/3/032071

Urone, P. P., Hinrichs, R., Dirks, K., \& Sharma, M. (2020). College physics. OpenStax College. https://assets. openstax.org/oscms-prodcms/media/documents /College_Physics-WEB_2s5sHvR.pdf

van Laar, E., van Deursen, A. J. A. M., van Dijk, J. A. G. M., \& de Haan, J. (2017). The relation between 21stcentury skills and digital skills: A systematic literature review. Computers in Human Behavior, 72, 577-588. https:/ / doi.org/10.1016/j.chb.2017.03.010

van Laar, E., van Deursen, A. J. A. M., van Dijk, J. A. G. M., \& de Haan, J. (2020). Determinants of 21stcentury skills and 21st-century digital skills for workers: A systematic literature review. SAGE
Open, 10(1), 1-14. https://doi.org/10.1177/ 2158244019900176

Wang, Q. (2008). A generic model for guiding the integration of ICT into teaching and learning. Innovations in Education and Teaching International, 45(4), 411-419. https:/ / doi.org/10.1080/147032908 02377307

Wartono, W., Hudha, M. N., \& Batlolona, J. R. (2018). How are the physics critical thinking skills of the students taught by using inquiry-discovery through empirical and theorethical overview? Eurasia Journal of Mathematics, Science and Technology Education, 14(2), 691-697. https://doi.org/10.12973/ejmste/80632

Webb, M., \& Gibson, D. (2015). Technology enhanced assessment in complex collaborative settings. Education and Information Technologies, 20(4), 675695. https:/ / doi.org/10.1007/s10639-015-9413-5

Worku, H., \& Alemu, M. (2021). Supportiveness of existing classroom culture to the implementation of dialogic teaching: Analysis of teacher-student interaction in physics teaching and learning. Pedagogical Research, 6(1), em0100. https:/ / doi.org/ $10.29333 / \mathrm{pr} / 11062$

Zacharia, Z. C., \& Olympiou, G. (2011). Physical versus virtual manipulative experimentation in physics learning. Learning and Instruction, 21(3), 317-331. https:/ / doi.org/10.1016/j.learninstruc.2010.03.001

Zais, R. (1976). Curriculum, principles and foundations. Harper \&. Row Publishers.

Zambrano, J., Kirschner, F., Sweller, J., \& Kirschner, P. A. (2019). Effects of prior knowledge on collaborative and individual learning. Learning and Instruction, 63(1), 101214. https://doi.org/10.1016/j.learnin struc.2019.05.011

Zhang, L., Kalyuga, S., Lee, C., \& Lei, C. (2016). Effectiveness of collaborative learning of computer programming under different learning group formations according to students' prior knowledge: a cognitive load perspective. Journal of Interactive Learning Research, 27(2), 171-192. https://www. learntechlib.org/primary/p/111825 


\section{APPENDIX 1}

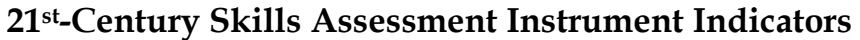

\begin{tabular}{|c|c|}
\hline Aspect & Indicator \\
\hline \multirow[t]{6}{*}{ Creativity } & Generate ideas clearly (both in-person and online) \\
\hline & Generate original ideas (both in-person and online) \\
\hline & Respond the problems with many alternative solution (both in-person and online) \\
\hline & 4. Find sources of information to solve problems (both in-person and online) \\
\hline & 5. Implement existing knowledge in solving a problem \\
\hline & Create new and unique product \\
\hline \multirow{7}{*}{ Critical Thinking } & 2. Evaluate someone's argument (both in-person and online) \\
\hline & 3. Provide feedback on someone's arguments (both in-person and online) \\
\hline & 4. Delivering explanations (both in-person and online). \\
\hline & 5. Summarizing the quality of information (both in-person and online) \\
\hline & 6. Understand how to use knowledge from one situation to another \\
\hline & 7. Understand the questions asked by others (both in-person and online) \\
\hline & 8. Asking questions to clarify (both in-person and online) \\
\hline \multirow[t]{13}{*}{ Collaboration } & 1. $\quad$ Divide the work of group members fairly \\
\hline & 2. Helping groups solve problems (both in-person and online) \\
\hline & 3. Provide useful feedback for team members (both in-person and online) \\
\hline & 4. Review team progress in completing tasks (both in-person and online) \\
\hline & 5. Help solve problems without asking the teacher for help \\
\hline & 6. Recognize and respect the opinions of group members \\
\hline & 7. Act according to their respective roles \\
\hline & 8. Be polite and kind to teammates (both in-person and online) \\
\hline & 9. Able to deliberation in groups for decision making (both in-person and online) \\
\hline & 10. Use time efficiently \\
\hline & 11. Discuss completing tasks (both in-person and online) \\
\hline & 12. Offer help to others when needed \\
\hline & 13. Complete tasks without having to be reminded \\
\hline \multirow[t]{5}{*}{ Communication } & 1. Using appropriate media tools to increase knowledge (both in-person and online) \\
\hline & 3. Listening actively when other people are talking (both in-person and online) \\
\hline & 4. Present all information clearly, concisely, and logically (both in-person and online) \\
\hline & 5. Use formal body language when presenting \\
\hline & 6. Answering questions clearly and concisely (both in-person and online) \\
\hline
\end{tabular}

(Adapted from: Partnership for 21st Century (2019) and R. Kelley et al. (2019) 


\section{APPENDIX 2}

\section{Indicators of the Validity of the Online-based Inquiry Learning Model}

\begin{tabular}{ll}
\hline Variable & Indicator \\
\hline Rationale & Background \\
& $\begin{array}{l}\text { Urgency } \\
\text { Purpose }\end{array}$ \\
\hline Theoretical Basis & Covers cognitive learning theory \\
& $\begin{array}{l}\text { Covers constructivist learning } \\
\text { theory }\end{array}$ \\
& $\begin{array}{l}\text { Based on the theoretical rationale } \\
\text { of the information processing } \\
\text { model group (The Information } \\
\text { Processing Family) }\end{array}$ \\
& $\begin{array}{l}\text { Contains inquiry-based learning } \\
\text { components }\end{array}$
\end{tabular}

Description

The background of the development of the Online-based Inquiry learning model.

The urgency of developing the Online-based Inquiry learning model.

The purpose of developing the Online-based Inquiry learning model.

Supporting theories relevant to the development of the Online-based Inquiry learning model.

Optimizing the ability of rational aspects in forming hypotheses, testing hypotheses, and drawing conclusions.

Covers discovery, problem solving, and collaboration processes.

theory

According to Joyce et al., (2016), provide stimulation from the environment to students to be able to organize data, formulate problems, build concepts and plan problem solving, and use verbal and nonverbal symbols.

Contains inquiry-based learning Contains inquiry-based learning components, namely: observing; formulate questions or hypothesize; collect information through books and other sources of information critically or carry out experiments or experiments; Analyze and interpret data.

Based on the theoretical rationale According to Holmfeld et al. (2012), accommodate students in activities, of networked learning such as: digital collaboration and digital communication; discussion and dialogue in groups; self-assessment in the learning process; access to digital learning resources; and scientific measures.

Use of ICT in Infusing level Student-centered and collaborative; ICT as a subject that cannot be separated from learning; Provides dispersed access to various digital resources; ICT-based assessment, student-centered, and using several types of assessment.

\begin{tabular}{|c|c|c|}
\hline \multirow[t]{9}{*}{ Syntax } & Syntax order & $\begin{array}{l}\text { Each phase of the Online-based Inquiry learning model is a logical } \\
\text { sequence of learning activities. }\end{array}$ \\
\hline & Syntax purpose & Each phase of the Online-based Inquiry learning model has a clear goal. \\
\hline & Syntax organization & $\begin{array}{l}\text { Each phase of the Online-based Inquiry learning model has a clear } \\
\text { organization of activities. }\end{array}$ \\
\hline & Teacher activities & $\begin{array}{l}\text { Each phase of the Online-based Inquiry learning model contains the } \\
\text { teacher's activities clearly. }\end{array}$ \\
\hline & Student activities & $\begin{array}{l}\text { Each phase of the Online-based Inquiry learning model contains the } \\
\text { activities of students clearly. }\end{array}$ \\
\hline & $\begin{array}{l}\text { Support the achievement of } \\
\text { learning objectives }\end{array}$ & $\begin{array}{l}\text { Each stage of the Online-based Inquiry learning model supports the } \\
\text { achievement of learning objectives. }\end{array}$ \\
\hline & Integrating ICT & $\begin{array}{l}\text { Each phase of the Online-based Inquiry learning model is integrated with } \\
\text { ICT. }\end{array}$ \\
\hline & Practicality & $\begin{array}{l}\text { Each phase of the Online-based Inquiry learning model can be } \\
\text { implemented. }\end{array}$ \\
\hline & $\begin{array}{l}\text { Accommodating the } \\
\text { development of } 21^{\text {st_Century }} \\
\text { Skills }\end{array}$ & $\begin{array}{l}\text { Each phase of the Online-based Inquiry learning model accommodates the } \\
\text { development of } 21^{\text {st-Century Skills. }}\end{array}$ \\
\hline \multirow[t]{7}{*}{ Social System } & $\begin{array}{l}\text { The relationship between } \\
\text { teachers and students }\end{array}$ & $\begin{array}{l}\text { Shows the pattern of the relationship between teachers and students } \\
\text { clearly. }\end{array}$ \\
\hline & \multirow[t]{2}{*}{ Student activity } & Individual activities are described clearly. \\
\hline & & Group activities are described clearly. \\
\hline & Teacher activity & $\begin{array}{l}\text { Teacher activities in each phase of the Online-based Inquiry learning } \\
\text { model are described clearly }\end{array}$ \\
\hline & Implementation & $\begin{array}{l}\text { The social system in the Online-based Inquiry learning model has a good } \\
\text { level of implementation. }\end{array}$ \\
\hline & Supports syntax & $\begin{array}{l}\text { The social system in the Online-based Inquiry learning model supports } \\
\text { syntax implementation.. }\end{array}$ \\
\hline & $\begin{array}{l}\text { Has a relationship with other } \\
\text { model components }\end{array}$ & $\begin{array}{l}\text { The social system in the Online-based Inquiry learning model has links } \\
\text { with other model components. }\end{array}$ \\
\hline
\end{tabular}




\begin{tabular}{|c|c|c|}
\hline Variable & Indicator & Description \\
\hline \multirow[t]{7}{*}{$\begin{array}{l}\text { Principle of } \\
\text { Reaction }\end{array}$} & Teacher behavior & $\begin{array}{l}\text { The teacher's behavior in each session of the Online-based Inquiry learning } \\
\text { model is described clearly. }\end{array}$ \\
\hline & \multirow[t]{3}{*}{ Teacher's reaction } & The teacher's reaction as a facilitator is described clearly. \\
\hline & & The teacher's reaction as a motivator is described clearly. \\
\hline & & The teacher's reaction as a supervisor is described clearly. \\
\hline & Implementation & $\begin{array}{l}\text { The principle of reaction in the Online-based Inquiry learning model } \\
\text { supports the implementation of the syntax. }\end{array}$ \\
\hline & Supports syntax implementation & $\begin{array}{l}\text { The reaction principle in the Online-based Inquiry learning model } \\
\text { supports the implementation of the syntax. }\end{array}$ \\
\hline & $\begin{array}{l}\text { Has a relationship with other } \\
\text { model components }\end{array}$ & $\begin{array}{l}\text { The reaction principle in the Online-based Inquiry learning model is } \\
\text { related to other model components. }\end{array}$ \\
\hline \multirow[t]{3}{*}{ Support System } & \multirow[t]{2}{*}{$\begin{array}{l}\text { Support the implementation of } \\
\text { learning }\end{array}$} & $\begin{array}{l}\text { Teacher Book supports the implementation of learning in accordance with } \\
\text { the Online-based Inquiry learning model. }\end{array}$ \\
\hline & & $\begin{array}{l}\text { Student Book supports the implementation of learning in accordance with } \\
\text { the Online-based Inquiry learning model. }\end{array}$ \\
\hline & $\begin{array}{l}\text { Has a relationship with other } \\
\text { model components }\end{array}$ & $\begin{array}{l}\text { The support system in the Online-based Inquiry learning model has links } \\
\text { with other model components. }\end{array}$ \\
\hline \multirow{4}{*}{$\begin{array}{l}\text { Instructional } \\
\text { effect and } \\
\text { nurturant effect }\end{array}$} & \multirow[t]{3}{*}{ Scope } & $\begin{array}{l}\text { Each phase of the Online-based Inquiry learning model covers } \\
\text { instructional effect and nurturant effect. }\end{array}$ \\
\hline & & The types of instructional effect and nurturant effect are described clearly. \\
\hline & & The types of instructional effect and nurturant effect are quite logical. \\
\hline & $\begin{array}{l}\text { Achievement of learning } \\
\text { objectives }\end{array}$ & $\begin{array}{l}\text { The types of instructional effect and nurturant effect describe the } \\
\text { achievement of learning objectives. }\end{array}$ \\
\hline
\end{tabular}


APPENDIX 3

\section{Indicators of Student E-book Practicality Instruments}

\begin{tabular}{|c|c|c|}
\hline Indicator & Sub-Indicator & Description \\
\hline \multirow[t]{3}{*}{ Implementation } & $\begin{array}{l}\text { The instructions are easy to } \\
\text { understand. }\end{array}$ & Instructions for using the student e-book are easy to understand. \\
\hline & $\begin{array}{l}\text { Easy to use with a laptop or } \\
\text { smartphone. }\end{array}$ & $\begin{array}{l}\text { There are no obstacles in using the student e-book with a laptop } \\
\text { or smartphone. }\end{array}$ \\
\hline & Worksheets are easy to implement. & Worksheets in the student e-books are easy to implement. \\
\hline \multirow[t]{6}{*}{ Usefulness } & $\begin{array}{l}\text { E-book connectivity provides } \\
\text { usefulness in obtaining information. }\end{array}$ & $\begin{array}{l}\text { The connectivity of the student e-book (connected to learning } \\
\text { management facilities/Google Classroom) make it easier for } \\
\text { students to obtain the information needed to study learning } \\
\text { materials. }\end{array}$ \\
\hline & $\begin{array}{l}\text { E-book connectivity provides } \\
\text { benefits in communication and } \\
\text { collaboration. }\end{array}$ & $\begin{array}{l}\text { The connectivity of the student e-book (connected to learning } \\
\text { management facilities/Google Classroom) make it easier for } \\
\text { students tocommunicate and collaborate. }\end{array}$ \\
\hline & Generate motivation and curiosity & $\begin{array}{l}\text { The problems in the student e-book raise motivation and } \\
\text { curiosity in studying learning materials. }\end{array}$ \\
\hline & $\begin{array}{l}\text { Forming an understanding of the } \\
\text { learning material.. }\end{array}$ & $\begin{array}{l}\text { The learning steps in the student e-book make it easier for } \\
\text { students to construct an understanding of the material. }\end{array}$ \\
\hline & A clear description of the material. & $\begin{array}{l}\text { The description of the material in the student e-book is easy to } \\
\text { understand. }\end{array}$ \\
\hline & Meeting current needs & $\begin{array}{l}\text { The student e-books can be used as teaching material books that } \\
\text { are relevant to the needs of the current era. }\end{array}$ \\
\hline \multirow[t]{5}{*}{$\begin{array}{l}\text { Applicability in physics } \\
\text { learning }\end{array}$} & $\begin{array}{l}\text { Generating interest in studying } \\
\text { physics. }\end{array}$ & $\begin{array}{l}\text { The student e-book keeps readers interested to participate in a } \\
\text { physics lesson. }\end{array}$ \\
\hline & Makes it fun to study physics. & $\begin{array}{l}\text { The student e-book keeps readers comfortable to read the } \\
\text { content. }\end{array}$ \\
\hline & Easy to use for physics lesson. & The student e-book is easy to use in a physics lesson. \\
\hline & Easy to observe physics phenomena. & $\begin{array}{l}\text { The student e-book make it easier for students to observe physics } \\
\text { phenomena. }\end{array}$ \\
\hline & Help in constructing knowledge. & $\begin{array}{l}\text { The student e-book is very helpful for students in constructing } \\
\text { their knowledge. }\end{array}$ \\
\hline \multirow[t]{2}{*}{ Time Allocation } & $\begin{array}{l}\text { One lesson can be carried out within } \\
\text { two hours of lessons. }\end{array}$ & $\begin{array}{l}\text { One lesson in the student e-books can be carried out in two hours } \\
\text { of lessons. }\end{array}$ \\
\hline & & Students are not in a hurry to participate in the lesson \\
\hline
\end{tabular}


APPENDIX 4

\section{Indicators of Teacher E-book Practicality Instruments}

\begin{tabular}{|c|c|c|}
\hline Indicator & Sub-Indicator & Description \\
\hline \multirow[t]{3}{*}{ Implementation } & $\begin{array}{l}\text { The instructions are easy to } \\
\text { understand }\end{array}$ & $\begin{array}{l}\text { The teacher e-book makes it easy for teachers to get a conceptual } \\
\text { framework about learning goals (includes the domains of attitudes, } \\
\text { knowledge, and skills). }\end{array}$ \\
\hline & Implementation. & $\begin{array}{l}\text { The teacher e-book facilitating teachers in applying the Online-based } \\
\text { Inquiry learning model. }\end{array}$ \\
\hline & $\begin{array}{l}\text { Provides convenience in } \\
\text { managing learning. }\end{array}$ & $\begin{array}{l}\text { The teacher e-book facilitates teachers in managing learning using } \\
\text { learning management tools. }\end{array}$ \\
\hline \multirow[t]{5}{*}{ Usefulness } & $\begin{array}{l}\text { Giving guidance to the } \\
\text { teacher. }\end{array}$ & $\begin{array}{l}\text { The teacher e-book guides teachers in the selection of relevant media, } \\
\text { tools, and learning resources. }\end{array}$ \\
\hline & & $\begin{array}{l}\text { The teacher e-book guides the teacher in the selection of techniques and } \\
\text { forms of instruments that will be carried out at each meeting. }\end{array}$ \\
\hline & & $\begin{array}{l}\text { The teacher e-book guides teachers in conducting assessments in each } \\
\text { domain of competence. }\end{array}$ \\
\hline & & $\begin{array}{l}\text { The teacher e-book guides teachers in assessing the improvement of } 21^{\text {st }} \\
\text { Century Skills }\end{array}$ \\
\hline & $\begin{array}{l}\text { Compatibility with the } \\
\text { student e-book. }\end{array}$ & The teacher e-book has compatibility with the student e-book. \\
\hline \multirow{3}{*}{$\begin{array}{l}\text { Keterpakaian dalam } \\
\text { pembelajaran fisika }\end{array}$} & Relevant & The material presented in the teacher e-book is relevant. \\
\hline & & Learning tools and materials in the teacher e-book are easily available. \\
\hline & Assessment rubric & $\begin{array}{l}\text { The assessment indicators in the scoring rubric are clear and easy to } \\
\text { observe. }\end{array}$ \\
\hline
\end{tabular}

\section{http://www.ejmste.com}

